\title{
S. A. Fábrica Votorantim e o setor têxtil paulista (1918-1939): os caminhos que levaram o grupo da falência à liderança industrial
}

S. A. Fábrica Votorantim and the São Paulo's textile sector (1918-1939): the paths that led the group from bankruptcy to the industrial leadership

Gustavo Pereira da Silva ${ }^{(1)}$

Armando João Dalla Costa (2)

(1) Universidade Federal de São Carlos

(2) Universidade Federal do Paraná

\section{Abstract}

Understanding the Brazilian economic groups presents a gap, especially in understanding how these groups were formed in the first half of the twentieth century. The Votorantim Group, eighth largest Brazilian group in 2007, emerged in the late nineteenth century, but gained its business definition in 1918, when it was acquired by businessman Antonio Pereira Ignacio. In the 1920 and 1930s, the major undertaking of Sociedade Anônima Fábrica Votorantim (SAFV) was a textile factory, located in Sorocaba (SP), close to the other group undertakings (railway, lime and cement, sale of land, hydroelectric power plant). Analyzing primary sources of SAFV (balance sheets, profit and loss statements, management reports) and surveys on the São Paulo industry, we noted its evolution to become the biggest textile company in the state of São Paulo in the 1930s, progress based on three factors: its constitution as a business group, its family management and its links to the São Paulo's financial sector.

\section{Keywords}

Votorantim; business group; textile.

JEL Codes L67; N66; N86.

\section{Resumo}

A compreensão dos grupos econômicos brasileiros apresenta uma lacuna, sobretudo, no entendimento de como esses grupos se formaram na primeira metade do século XX. O Grupo Votorantim, oitavo maior grupo brasileiro em 2007, surgiu no final do século XIX, mas ganhou sua definição empresarial em 1918, quando foi adquirido pelo empresário Antonio Pereira Ignácio. Nas décadas de 1920 e 1930, o principal empreendimento da Sociedade Anônima Fábrica Votorantim (SAFV) era a fábrica têxtil, localizada em Sorocaba (SP), próxima dos outros empreendimentos do grupo (ferrovia, cal e cimento, venda de terrenos, usina hidrelétrica). Analisando fontes primárias da SAFV (balanços patrimoniais, demonstrações de lucros e perdas, relatórios de diretoria) e os levantamentos sobre a indústria paulista, evidenciamos sua evolução ao posto de principal empresa têxtil paulista na década de 1930, progresso apoiado em três fatores: sua constituição como um grupo econômico, sua administração familiar e suas ligações com o setor financeiro paulista.

\section{Palavras-chave}

Votorantim; grupo econômico; têxtil.

Códigos JEL L67; N66; N86. 


\section{Introdução}

Nas décadas iniciais do século XX, o têxtil se notabilizava como o mais expressivo setor industrial nacional, tanto no nível estadual quanto federal: no ano de 1919, 29\% do produto industrial brasileiro teve origem neste setor, cifra análoga à sua participação no cômputo da indústria paulista, sendo que São Paulo abrigava 30\% das fábricas têxteis brasileiras e $27 \%$ do capital investido no setor, além de $34 \%$ dos operários nacionais (Negri, 1996, p. 37; Baer, 2002, p. 60; Loureiro, 2007 p. 32).

Dos ramos que compunham o setor têxtil no estado de São Paulo no ano de 1928 - fiação e tecelagem de algodão; fiação e tecelagem de juta; fábricas de seda natural e artificial (rayon); as malharias e as fábricas de lã - o ramo algodoeiro era o principal, pois, enquanto suas fábricas representavam $31,5 \%$ do setor, ao mesmo tempo, nelas estavam $64,5 \%$ do capital, somavam $60,6 \%$ dos trabalhadores e $74,6 \%$ da força motriz, elementos que reunidos permitiam ao ramo algodoeiro alcançar $43,4 \%$ da produção do setor (Aureliano, 1999, p. 40; Loureiro, 2007, p. 33).

Uma das maiores fábricas têxteis paulistas nas décadas iniciais do século XX era a Sociedade Anônima Fábrica Votorantim, localizada na cidade de Sorocaba. A empresa foi criada em 1891 pelo banco União de São Paulo e, com sua falência em 1918, arrematada pelos empresários Antonio Pereira Ignácio e Francisco Scarpa em janeiro daquele ano. Nos vinte anos subsequentes, a Fábrica Votorantim converteu-se de parte da massa falida do banco para o posto de principal firma têxtil paulista - segundo o montante do capital investido - no ano de 1931, fato que se repetiria entre 1935-1937.

Em que pese relevantes trabalhos terem se debruçado sobre a indústria têxtil paulista, tais estudos o fizeram de uma maneira setorial, na maioria das vezes, sem tomar como objeto de análise uma empresa específica, suas políticas de gestão e seus resultados contábeis no período do Entreguerras. ${ }^{1}$ No caso da Fábrica Votorantim, os trabalhos arrolados demonstram uma preocupação maior com os fatores de crescimento do grupo em meio ao seu processo de internacionalização, que se adensou na década de 1980, 1 Stein, 1979; Cano, 1981; Loureiro, 2007; Baer, 1975; Carone, 2001; Cano, 1981; Negri, 1996; Suzigan, 2000; Dean, 1971; Versiani; Versiani, 1978; Ribeiro, 1988. Um estudo específico sobre uma das mais importantes firmas têxteis fluminenses é de Elisabeth von der Weid: O fio da meada: estratégia de expansão de uma indústria têxtil: Companhia América Fabril, 18781930. Rio de Janeiro: FCRB: CNI, 1986. 
momento em que a Votorantim já havia se consolidado no setor industrial de base, permanecendo, então, lacunas sobre o evolver dos negócios têxteis, atividade central do grupo até o final dos anos 1930 e que teria viabilizado financeiramente os novos investimentos. ${ }^{2}$

Ademais, a lacuna apontada é de extensão mais ampla se considerada a escassez de informações sobre a origem dos maiores grupos econômicos nacionais, lista que, para o ano de 2007, colocava o Grupo Votorantim como o principal conglomerado industrial de origem privada/familiar, ao lado de empresas estatais e bancos que comungam o fato de terem surgido antes da década de 1960 (Aldrighi; Postali, 2010, p. 355-356). ${ }^{3}$

Diante disso, este artigo tem como objeto o evolver da Sociedade Anônima Fábrica Votorantim (SAFV) - doravante Grupo Votorantim (referente às empresas do grupo) ou Fábrica Votorantim (referindo-se somente à firma têxtil) -, razão social da fábrica têxtil e de investimentos paralelos que compunham o grupo econômico liderado por Antonio Pereira Ignacio e José Ermírio de Moraes nas décadas de 1920 e 1930. O foco recai sobre a atuação da Fábrica Votorantim no setor têxtil paulista entre 1919-1939, buscando compreender como ocorreu a reestruturação da empresa, bem como do grupo, após a falência do Banco União de São Paulo em 1918, inaugurando uma nova fase em que a Fábrica Votorantim se transformaria na maior firma têxtil de São Paulo nos anos 1930. Para tanto, utilizamos as demonstrações contábeis da Sociedade Anônima Fábrica Votorantim (balanços gerais, demonstrações de lucros e perdas), os relatórios da diretoria do Grupo Votorantim e os levantamentos sobre a indústria paulista no Entreguerras (Estatística Industrial de São Paulo e Boletim da Diretoria de Indústria e Comércio do Estado de São Paulo).

De antemão, notamos que a trajetória do Grupo Votorantim, iniciada com a construção da Fábrica Têxtil Votorantim na cidade de Sorocaba em

2 Santos, 2008; Pedrosa, 2015. Devemos registrar que alguns trabalhos se reportaram às figuras-chave para o desenvolvimento do Grupo Votorantim, caso de: Scantimburgo, J. José Ermírio de Moraes: o homem, a obra. São Paulo: Companhia Editora Nacional, 1975; e Pastore, J. Antonio Ermírio de Moraes: memórias de um diário confidencial. São Paulo: Planeta, 2013. Nesta mesma linha hagiográfica situa-se a obra de Caldeira, J. Votorantim 90 anos: uma história de trabalho e superação. São Paulo: Mameluco, 2007.

3 Os dez maiores grupos econômicos do Brasil em 2007 eram, em ordem crescente de receita bruta (em parênteses o ano de fundação): Fiat (1899), Gerdau (1909), Votorantim (1892), Ambev (1999), Telefônica (1924), Banco do Brasil (1808), Itaú (1945), Vale (1942), Bradesco (1943) e Petrobras (1953) (Aldrighi; Postali, 2010, p. 355-356). Há trabalhos que traçam um histórico dos grupos econômicos brasileiros, mas que não empreenderam análises mais específicas sobre o período da primeira metade do século XX, caso de Bonelli (1998) e Gonçalves (1999). 
1891 pelo banco União de São Paulo, corrobora as análises que pontuam o início da década de 1890 - com as medidas de estímulo ao crédito, facilitação à formação de empresas e certa proteção tarifária - como um cenário favorável ao surto industrial brasileiro, em que os bancos universais passaram a investir na indústria (Fishlow, 1972; Stein,1979; Cano, 1981; Baer; 1975; Versiani; Versiani, 1978; Marcondes e Hanley, 2010; Suzigan, 2000; Lima; Sanson, 2008).

O evolver da Votorantim no setor têxtil paulista durante a Primeira República também demonstra uma congruência com a historiografia tradicional, quando ela indica a década de 1920 como um momento importante na formação de capacidade instalada - fusos e teares - que seria a base para a retomada do crescimento no início dos anos 1930, junto às políticas de sustentação da renda no setor cafeeiro (Stein, 1979; Versiani; Versiani, 1978; Fishlow, 1972; Suzigan, 2000).

Todavia, existem especificidades sobre as maiores empresas têxteis que a historiografia tradicional pouco abordou. Sem olvidar a importância dos pequenos e médios estabelecimentos na indústria paulista do início do século $\mathrm{XX},{ }^{4}$ devemos salientar que o setor têxtil era extremamente oligopolizado, composto por fábricas como a Belenzinho (São Paulo-SP) e a Votorantim (Sorocaba-SP), as quais, em 1935, somadas tinham boa parte do capital, força motriz, maquinário e trabalhadores do ramo têxtil algodoeiro em suas fábricas. ${ }^{5}$ A primeira era pertencente ao conglomerado Indústrias Reunidas Francisco Matarazzo que, em 1925, atuava também nos setores alimentício, de óleos e derivados, metalurgia, químico, bancário, além do têxtil (Pedrosa, 2015, p. 170). Por sua vez, a Sociedade Anônima Fábrica Votorantim na década de 1930 atuava na fiação e tecelagem de algodão, óleos vegetais e subprodutos, sabão e saponáceos, olarias, cimento e cal, adubos e colas, fornecimento de energia elétrica, além de possuir uma ferrovia. ${ }^{6}$

Segundo Cano (1981, p. 225) e Versiani e Versiani (1978, p. 128), a explicação para tamanha diversificação das maiores empresas estaria na busca por diluir os riscos ao atuar conjuntamente em diversos setores, ou seja,

5 No ano de 1935, a fábrica Belenzinho e a Votorantim reunidas contabilizavam 18\% do capital das fábricas têxteis algodoeiras do estado de São Paulo, 12\% do operariado, 15\% da força motriz, $14 \%$ dos fusos e $13 \%$ dos teares (DEIC/SAIC/SP, 1935).

6 DEIC/SAIC/SP, 1937, p. 45, 126, 157, 174, 196, 198, 199 e 246. 
seria uma escolha dos grandes grupos em integrar seus investimentos. Dean (1971, p. 72) ressalta que grupos como Matarazzo e Votorantim, que atuavam em uma economia brasileira caracterizada, nas décadas iniciais do século XX, por um mercado pouco integrado, dependente de matérias-primas e com fragilidades no fornecimento energético, visavam diminuir as incertezas e, para tanto, assumiam os investimentos em setores diversificados, dessa forma, situando a diversificação como uma necessidade das maiores empresas.

A formação do grupo Votorantim se alinha ao exposto por Dean (1971) e, ademais, busca enquadrar a evolução do conglomerado sorocabano junto ao surgimento dos grupos econômicos brasileiros na primeira metade do século XX, que surgiram concomitantemente em outros países de economias relativamente atrasadas, como na America Latina e Ásia (Colpan; Hikino, 2016, p. 2-3). Para viabilizar a produção da unidade têxtil (Fábrica Votorantim), o banco União de São Paulo teve de resolver a questão energética ao montar uma pequena central hidrelétrica no rio Sorocaba e construir uma ferrovia para garantir o acesso à matéria-prima e escoamento da produção, empreendimentos que se impuseram aos investidores. A esses empreendimentos seriam somados outros, como a fábrica de cimento Rodovalho em 1918, configurando o grupo Votorantim. A reunião de tais investimentos diversificados - além das ligações com o setor financeiro paulista e a administração familiar do grupo - possibilitou a evolução da Fábrica Votorantim no setor têxtil paulista na década de 1920, até alcançar a liderança nos anos 1930.

\section{Sociedade Anônima Fábrica Votorantim: as origens de um grupo econômico brasileiro}

O enquadramento teórico das grandes empresas de economias emergentes no começo do século XX buscou no conceito de grupos econômicos uma melhor compreensão deste objeto. ${ }^{7}$ Em que pese os grupos econômicos não serem conceituados de maneira unívoca, as definições mais usuais

7 Os grupos econômicos receberam diferentes nomenclaturas nos países emergentes: na Coreia do Sul são os chaebols; na Índia os business houses; na Turquia as holding companies; e, na América Latina, se consagrou, inclusive no Brasil, o termo grupos econômicos (Kim; Kandemir; Cavusgil, 2004, p. 14). 
os descrevem como conjuntos de empresas que podem ser juridicamente independentes, mas que atuam de maneira unificada por meio de laços formais (patrimônio) e/ou informais (família). ${ }^{8}$ Esses grupos caracterizam-se pela atuação diversificada que, no caso dos grupos brasileiros, deve se dar pelo menos em três setores industriais (Aldrighi; Postali, 2010, p. 371).

A união com outras empresas independentes para formar grupos econômicos tendia a minimizar os obstáculos à atuação de tais companhias em mercados nascentes, diminuindo eventuais custos produtivos e comerciais. Questões fundamentais no cotidiano empresarial, como o acesso ao crédito, às fontes de matérias-primas, ao transporte das mercadorias finais, a instabilidade dos marcos regulatórios, a diversidade dos produtos e as próprias flutuações econômicas tinham na formação de grupos econômicos uma resposta às condicionalidades de economias atrasadas (Leff, 1978, p. 666-675; Barbero, 2011, p. 5-6; Kim; Kandemir; Cavusgil, 2004, p. 3).

A comandar os grupos econômicos, como no caso brasileiro, comumente vemos famílias - Ermírio de Moraes, Gerdau, Setúbal, Vilela entre outras - que detêm posições de controle nestas alianças de empresas. ${ }^{9}$ Articuladas em uma cadeia de gestão piramidal, ou eventualmente como holdings, essas famílias comandam as empresas por meio do controle acionário do grupo, condição que pode ser resultado de um único grande acionista - o fundador ou comprador da empresa - ou de alguns familiares com posse relevante de papéis do grupo, sendo que alguns desses indivíduos traduzem o controle da família com a participação direta em posições de controle estratégico, como a presidência ou gerência (Granovetter, 2005, p. 433; Colpan; Hikino, 2010, p. 16; Fernandez-Perez, 2010, p. 148; Fernandez-Perez; Casanova, 2012, p. 281).

Entre os dez maiores grupos econômicos brasileiros em 2007 constava o Grupo Votorantim, notadamente o maior dos grupos privados a atuar na indústria e cujas origens remontam ao final do século XIX. Em julho de 1891, o Banco União de São Paulo adquiriu terras na localidade paulista

8 Esta caracterização dos grupos econômicos enquanto conjunto de empresas independentes que atuam de maneira congregada pode ser encontrada em Granovetter (2005, p. 429), Khanna; Yafhe, (2007, p. 331), Colpan; Hikino (2010, p. 17) e Gonçalves (1991, p. 181).

9 Em 2007, dos 50 maiores grupos econômicos atuando no mercado brasileiro, 15 eram comandados por famílias nacionais, enquanto 21 eram controlados por firmas estrangeiras que podiam ser firmas familiares -, 8 grupos eram dirigidos por firmas privadas e/ou fundos de pensão nacionais, 5 grupos eram estatais e 1 grupo era chefiado de maneira conjunta por uma família brasileira e uma empresa estrangeira (Aldrighi; Postali, 2010, p. 372). 
de Sorocaba. ${ }^{10}$ A região era o principal centro algodoeiro de São Paulo e nas terras compradas situava-se uma cachoeira de nome Votorantim (no Rio Sorocaba). ${ }^{11}$ Essa queda d'água possibilitou ao banco solucionar uma questão-chave no funcionamento de sua Fábrica de Chitas Votorantim, ${ }^{12}$ unidade têxtil formada em 1891 e que passou a funcionar no ano seguinte, quando a pequena usina hidrelétrica construída pelo banco também foi concluída e passou a alimentar os teares e fusos da fábrica. ${ }^{13}$ Os dois empreendimentos foram complementados pelo banco que, a fim de viabilizar a chegada de matéria-prima e o escoamento da produção, engendrou uma ferrovia - a Estrada de Ferro Votorantim - a qual, apesar de sua extensão de somente oito quilômetros, servia para interligar o nascente distrito de Votorantim à cidade de Sorocaba, onde se encontrava com os trilhos da Estrada de Ferro Sorocabana unindo o mercado local ao estadual (EFEV, p. 1,1980$).{ }^{14}$

A conjuntura favorável aos investimentos industriais regrediu a partir de 1914, com as agruras econômicas impostas pela I Guerra Mundial, sobretudo com a diminuição dos fluxos comerciais do exterior, implicando em dificuldades na obtenção de matérias-primas - caso dos tecidos ingleses posteriormente finalizados no Brasil - e equipamentos. Ademais, com a queda nos preços do café, houve uma fuga de cambiais do sistema bancário paulista, gerando a falência de algumas instituições financeiras (Saes, 1986, p. 144; Villela e Suzigan, 1973, p. 128). Uma delas foi o Banco União de São Paulo que, em 9 de janeiro de 1918, leiloou seus ativos, entre eles a Fábrica Têxtil Votorantim (fiação, tecelagem e estamparia), que foi

10 Criado em janeiro de 1890, o Banco União de São Paulo tinha como presidente o senador Antonio de Lacerda Franco e em sua diretoria outros representantes do grande capital cafeeiro, sendo que, em 1892, era o maior banco paulista de acordo com o volume de seus ativos (Hanley, 2005, p. 155).

11 No início do século XX, a região de Sorocaba era responsável por $80 \%$ da produção de algodão paulista (Carone, 2001, p. 93).

12 Chita era um tecido de algodão importado, principalmente da Inglaterra, e posteriormente estampado no Brasil.

13 Como a maior parte da produção energética do estado de São Paulo se destinava ao consumo doméstico, os empreendimentos industriais tinham na viabilização energética um grande desafio ao funcionamento de suas instalações. Disto vinha a preferência por situar as plantas industriais próximas aos rios e suas quedas d'água, que permitiam a construção de pequenas usinas hidrelétricas que alimentariam as fábricas (Carone, 2001, p. 81-86; Saes, 2010, p. 112).

14 Inicialmente, a Estrada de Ferro Votorantim contava com 5 locomotivas, 30 vagões de carga, 8 carros de passageiros e 1 carro especial para autoridades, além de 1 carro fúnebre (EFEV, p.1, 1980). 
arrematada pelo empresário português Antonio Pereira Ignácio e o italiano Francisco Scarpa - que até então eram fornecedores da fábrica ${ }^{15}$ - além de outros acionistas minoritários, pelo valor de 5 mil contos de réis, montante tido como oito vezes menor que o valor dos ativos adquiridos na região de Sorocaba, pois além da unidade têxtil, com seus estoques e maquinários, eles se tornaram proprietários da Estrada de Ferro Votorantim e de jazidas de cal (Caieiras de Itupararanga) as quais também eram atendidas pela ferrovia particular (SAFV, 1918-1919; Marcovitch, 2009, p. 234).

Tabela 1 Empresas componentes do Grupo Votorantim, 1918-1929

\begin{tabular}{lrrrr}
\hline Nome da empresa & Ano de criação & Cidade & $\begin{array}{r}\text { Produção/ } \\
\text { Finalidade }\end{array}$ \\
\hline Fábrica Votorantim & 1892 & Votorantim (SP) & tecidos de algodão \\
\hline Fábrica Rodovalho & 1892 & São Roque (SP) & cimento \\
\hline Caieiras de Itupararanga & Desconhecido & Sorocaba (SP) & cal \\
\hline Estrada de Ferro Elétrica Votorantim & 1893 & Sorocaba (SP) & transporte \\
\hline
\end{tabular}

Fonte: SÃO PAULO. Diário Oficial do Estado de São Paulo, 30/06/1922, p. 1922; 15/02/1923, p. 1923; 14/02/1925, p. 1233; 12/02/1926, p. 1243; 15/02/1928, p. 1471; 23/02/1930, p. 1995.

Em virtude de desavenças com o sócio, Francisco Scarpa vendeu sua participação na Votorantim para Pereira Ignácio por dois mil contos de réis, tendo recebido do português também a Fábrica de Óleos Santa Helena. Pereira Ignácio aceitou a oferta e fez desta empresa seu principal investimento, concentrando esforços no setor têxtil com o controle acionário da Fábrica Votorantim e dos demais empreendimentos do grupo (Marcovitch, 2009, p. 236). ${ }^{16}$

15 Antonio Pereira Ignácio fornecia algodão descaroçado por meio de sua empresa, a Fábrica de Óleos Santa Helena, situada em Sorocaba (SP). O italiano Francisco Scarpa, através da F. Scarpa \& Filho, casa importadora de gêneros diversos, tinha um armazém dentro das instalações da Fábrica Votorantim para atender aos funcionários da firma (Lloyd et al., 1913, p. 651 apud http://www.novomilenio.inf.br/santos/h0300g39i.htm.)

16 Antonio Pereira Ignácio, português que chegou ao Brasil em $1884 \mathrm{com} 10$ anos de idade para viver com sua família na cidade paulista de Sorocaba, iniciou a trajetória econômica no Rio de Janeiro, trabalhando na casa importadora de tecidos do português João Reinaldo Faria. Com o cabedal acumulado, voltou para a região sorocabana no final do XIX e investiu no setor algodoeiro, chegando a ser proprietário de 14 empresas descaroçadoras de algodão espalhadas pela cidade de Boituva, Porto Feliz, Tatuí e Conchas, localidades situadas entre Piracicaba e Sorocaba. Utilizando a mesma matéria-prima, ele montou em 1905, na cidade de Sorocaba, a Fábrica de Óleos Santa Helena, que descaroçava o algodão a ser vendido às empresas têxteis e também produzia o óleo. No setor têxtil, ele ainda adquirira três tecelagens: Fábrica Paulistana, Fábrica Luzitânia e Fábrica Lucinda. Ademais, Pereira Ignácio diversificara 
Esse controle é evidenciado pelo quadro de acionistas do Grupo Votorantim em 15 de fevereiro de 1924, ao demonstrar que Antonio Pereira Ignácio (presidente do Grupo) tinha 99,44\% das ações do grupo - 12.500 ações em seu nome e mais 12.360 ações em nome da Pereira Ignácio \& Cia., que era a reunião de seus diversos empreendimentos individuais. Ademais, seus filhos Paulo e João Pereira Ignácio possuíam cada um 20 ações ( $0,08 \%$ dos papéis), o que punha em mãos da família um total de $99,60 \%$ das 25.000 ações em que se dividia o capital do grupo. ${ }^{17}$

Concentrando suas atividades principais no ramo têxtil, a Fábrica Votorantim galgaria postos, entre 1919-1937, que a conduziriam de uma posição de fragilidade financeira quando de sua venda para Pereira Ignácio à liderança deste que era o principal setor da indústria paulista e nacional.

\section{A Fábrica Votorantim em meio à crise no setor têxtil paulista (1919-1928)}

Após enfrentar dificuldades com a reposição de maquinário e fornecimento de matérias-primas durante a I Guerra Mundial (1914-1918), a indústria têxtil nacional iniciaria uma nova fase de investimentos na década de 1920. Favorecida, mesmo que indiretamente, por uma taxa de câmbio mais valorizada, principalmente entre 1924-1926, além de contar com a expansão dos meios de pagamentos, a importação de máquinas para as firmas algodoeiras sextuplicaria entre 1921-1926 (Suzigan, 2000, p. 159-160; Cano, 2012, p. 903; Negri, 1996, p. 37).

A ampliação da capacidade produtiva na década de 1920 ocorreu de forma análoga nas firmas têxteis paulistas, sendo o estado de São Paulo responsável pela produção de aproximadamente metade dos tecidos de algodão nacionais no decênio. ${ }^{18}$ Uma das principais empresas têxteis paulistas era a Fábrica Votorantim que, em 1920, encontrava-se na quinta

seus negócios comprando a Companhia Telefônica Sul Paulista e a Fábrica de Cimento Rodovalho (Marcovitch, 2009, p. 235; Caldeira, 2007, p. 18).

17 Os demais acionistas da S. A. Fábrica Votorantim em fevereiro de 1924 eram: Zeferino de Freitas Guimarães, Antonio Oliveira Penteado, A. de Carvalho e Silva, Jorge Nielsen, Mario Goulart de Faria, sendo que cada um deles possuía 20 ações (SAFV, 1923, p. 13).

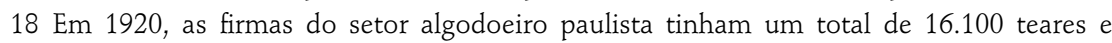
524.000 fusos que produziram 186,5 milhões de metros de tecidos. Já, em 1928, elas possuíam 22.800 teares e 730.800 fusos que produziram 191,1 milhões de metros de tecidos (Cano, 1981, p. 293). 
posição entre as companhias produtoras de tecidos de algodão no Estado, segundo o capital investido, ficando atrás de firmas da capital paulista. ${ }^{19}$ Conforme a tabela 2, vemos que a Fábrica Votorantim era uma importante empresa têxtil na década de 1920, que produzia $8 \%$ do total de tecidos de algodão no estado de São Paulo e 5\% da oferta nacional entre 1920-1930.

Tabela 2 Produção de tecidos de algodão da Fábrica Votorantim, do estado de São Paulo e do restante do Brasil, 1918-1930 - em milhões de metros

\begin{tabular}{l|r|r|r|r|r|r|r|r|r}
\hline & $\mathbf{1 9 1 8}$ & $\mathbf{1 9 1 9}$ & $\mathbf{1 9 2 0}$ & $\mathbf{1 9 2 1}$ & $\mathbf{1 9 2 2}$ & $\mathbf{1 9 2 3}$ & $\mathbf{1 9 2 5}$ & $\mathbf{1 9 2 9}$ & $\mathbf{1 9 3 0}$ \\
\hline Resto do país & 347 & 409 & 400 & 355 & 410 & 452 & 330 & 329 & 341 \\
\hline Estado de São Paulo & 147 & 175 & 187 & 198 & 217 & 488 & 206 & 149 & 135 \\
\hline Votorantim & 13 & 11 & 16 & 16 & 21 & 24 & 20 & 16 & 17 \\
\hline
\end{tabular}

Fonte: Cano (1981, p. 293); SÃO PAULO. Diário Oficial do Estado de São Paulo, 30/06/1922, p. 1922; 15/02/1923, p. 1923; 14/02/1925, p. 1233; 12/02/1926, p. 1243; 22/03/1931 p. 2327.

No caso da Fábrica Votorantim, as instalações sorocabanas, que sofriam pela obsolescência dos equipamentos, receberam máquinas importadas ao final da I Guerra Mundial, sob a nova administração de Pereira Ignácio. O número de teares era de 1.109 peças e o de fusos era de 36.000 no ano de 1916, subiu para 1.300 teares e 46.000 fusos em 1920, permanecendo o número de operários igual nos dois anos arrolados. ${ }^{20}$ Junto aos aprimoramentos nas máquinas já existentes, esses novos fusos e teares possibilitaram à Votorantim, entre 1918-1923, dobrar sua produção - de quase 13 milhões de metros de tecidos para pouco mais de 24 milhões de metros, produção que se tratava de chitas, morins, zefires, lenços, gaze, crepes e toalhas. ${ }^{21}$

Na década de 1920, o Grupo Votorantim tinha uma gama de recursos produtivos em que se destacava a fábrica têxtil, empreendimento que era responsável por $80 \%$ das receitas no período, conforme a tabela 3. Além

19 Em 1920, as maiores fábricas de tecidos de algodão do Estado de São Paulo, segundo o capital investido, eram (capital em contos de réis): Cia. Nacional de Tecidos de Juta (10.000); Cotonifício Rodolfo Crespi (7.729); Fábrica de Tecidos Labor (7.600); Fiação, Tecelagem e Estamparia Jafet (6.419); e Sociedade Anônima Fábrica Votorantim (6.000) (DEIC/SACOP/ SP, fev-mar, 1922, p. 60-63).

20 DEIC/SACOP/SP, ago-set. 1918, p. 387 e fev-mar, 1922, p. 60-63.

21 No Relatório da Diretoria do Grupo Votorantim referente ao ano de 1923 consta que "Adquirimos o estabelecimento em julho de 1917, sendo que, nesse ano, foi quase nula a sua eficiência de trabalhos, em virtude da reforma geral que a fábrica necessitava". Ademais, "no tocante aos melhoramentos aplicados nos maquinismos existentes, verificamos, com a aplicação prática na fiação, que o processo de uniformização de uma só canilha produz um aumento de $26 \%$, com diminuição de $20 \%$ da mão-de-obra" (SAFV, 1923, p. 3). 
dos investimentos na fábrica têxtil, ocorreu a eletrificação e o alargamento de bitola dos trilhos da Estrada de Ferro Votorantim que atendia a fábrica têxtil, as Caieiras de Itupararanga (Sorocaba-SP) e a Fábrica de Cimento Rodovalho (São Roque-SP). ${ }^{22}$

Tabela 3 Receitas do Grupo Votorantim, 1921-1927 - valores reais em contos de réis (ano base $=1921)$

\begin{tabular}{lrrrrrr}
\hline & $\mathbf{1 9 2 1}$ & $\mathbf{1 9 2 2}$ & $\mathbf{1 9 2 4}$ & $\mathbf{1 9 2 5}$ & $\mathbf{1 9 2 7}$ \\
\hline Votorantim (fábrica têxtil) & 5.337 & 2.773 & 5.378 & 3.697 & 2.742 \\
\hline Itupararanga (cal) & 438 & 208 & 264 & 244 & 690 \\
\hline Rodovalho (cimento) & 83 & 40 & 29 & 17 & 31 \\
\hline Diversos & 419 & 431 & 596 & 102 & 0 \\
\hline Estrada de Ferro Elétrica & & & 45 & 61 & 552 \\
\hline Seção de Terrenos & & & & 410 & 534 \\
\hline Renda de imóveis & 41 & 27 & 32 & 9 & \\
\hline Total & 6.319 & 3.482 & 6.346 & 4.542 & 4.549 \\
\hline
\end{tabular}

Fonte: SÃO PAULO. Diário Oficial do Estado de São Paulo, 30/06/1922, p. 1922; 15/02/1923, p. 1923; 14/02/1925, p. 1233; 12/02/1926, p. 1243; 15/02/1928, p. 1471.

Nota: os dados foram extraídos das Declarações de Lucros e Perdas publicadas no Diário Oficial do Estado de São Paulo. A diferença entre a soma dos itens da Receita e o total se deve ao arredondamento dos dados. Para obter os valores reais foi utilizado o Deflator Implícito do PIB elaborado pelo ipeadata (http://www.ipeadata.gov.br/) com base no trabalho de Haddad, Claudio Luiz da Silva. Crescimento do produto real no Brasil, 1900-1947. Rio de Janeiro: Fundação Getúlio Vargas, 1978.

Pela tabela 3, vemos que as receitas do Grupo Votorantim apresentaram queda de $28 \%$ entre os anos 1921-1927, sobretudo em virtude da crise no setor têxtil algodoeiro paulista que, entre os anos 1924-1928, teve um declínio de $17 \%$ em sua produção - no restante do país houve crescimento de $12 \%$ na produção de tecidos de algodão. ${ }^{23}$ Especificamente, a queda

22 A eletrificação e o alargamento da bitola proporcionaram um crescimento no fluxo de passageiros e no transporte de mercadorias pela Estrada de Ferro Elétrica Votorantim, visto que, em 1918, foram comercializados 62.087 bilhetes de passageiros e transportadas 69.054 toneladas de mercadorias. Ao passo que, em 1923, foram vendidos 174.122 bilhetes de passageiros e transportados 948.829 toneladas de mercadorias (SAFV, 1923, p. 5).

23 As agruras do setor têxtil paulista entre 1926-1928 explicavam-se pela maior inserção dos tecidos estrangeiros no mercado nacional - sobretudo os ingleses -, sendo que tais mercadorias tinham uma grande demanda em virtude de sua qualidade mais elevada e de preços competitivos, o último fator em virtude da baixa proteção alfandegária em contexto de crescimento dos preços internos. Ademais, a capacidade produtiva nacional foi amplamente acrescida na década de 1920, acirrando a concorrência nos mercados regionais a partir da formação de novas empresas, como no Sul do Brasil (Cano, 1981, p. 180; Luz, 1975, p. 179; 
nas receitas no ano de 1925, por exemplo, foi atribuída no Relatório da Diretoria da Fábrica Votorantim à longa estiagem ocorrida no estado de São Paulo naquele ano, que gerou uma crise energética, diminuindo os dias de trabalho e, consequentemente, a produção têxtil. ${ }^{24}$ Para atenuar o cenário adverso, a Votorantim manteve a rotina de não distribuir dividendos, medida que vinha desde 1921 e se estenderia até 1931, como forma de capitalizar a empresa em meio à difícil conjuntura no setor têxtil. ${ }^{25}$

Ainda para enfrentar a crise, em 1926 o Grupo Votorantim levantou um empréstimo em Londres que deveria ser quitado em vinte anos, cujo serviço da dívida representou $25 \%$ das despesas e $32 \%$ do passivo do conglomerado no ano seguinte, convertendo-se na maior conta do passivo até ser quitado em 1938. Uma das explicações para a obtenção destes capitais estava nos nexos entre a Votorantim e grandes financistas, uma vez que, entre 1922-1931, o grupo tinha os seguintes membros em seu Conselho Fiscal: Manoel de Barros Loureiro; Araújo Costa \& Cia.; e o Banco do Comércio e Indústria do Estado de São Paulo (Comind), representado em alguns dos relatórios por Numa de Oliveira, presidente de seu Conselho Administrativo. ${ }^{26}$ Este banco, a principal casa bancária nacional a atuar no estado de São Paulo nos anos 1920, caracterizava-se pela participação de seus dirigentes na diretoria de outras companhias, tendo a casa forte atuação no financiamento do grande capital cafeeiro paulista, ${ }^{27}$ em uma simbiose entre grupos econômicos e instituições financeiras que garantia a provisão de capital aos negócios industriais, inclusive nas conjunturas econômicas adversas (Granovetter, 2005, p. 434). ${ }^{28}$

Suzigan, 1971, p. 94; Stein, 1979, p. 130-131).

24 SÃO PAULO, 12/02/1926, p. 1242.

25 (SÃO PAULO, 12/02/1926, p. 1242; 15/02/1928, p. 1471; 16/02/1928, p. 1953). O Relatório da Diretoria da S. A. Fábrica Votorantim para o ano de 1925 diz o seguinte acerca dos dividendos: "Não julgando ainda a Diretoria oportuna a ocasião para distribuir dividendos por assim a exigirem os interesses sociais, pede a vossa aprovação a proposta de serem levados a conta de lucros suspensos os proventos auferidos a constantes do balanço ora analisado". 26 SÃO PAULO, 15/02/1923, p. 1184; 14/02/1925, p. 1233; 12/02/1926, p. 1243; 15/02/1928, p. 1471; 23/02/1930, p. 1995; 22/03/1931, p. 2327; 25/02/1932, p. 15.

27 Em 1907, Antonio Prado e Francisco Antonio de Souza Queiroz eram diretores do Banco do Comércio e Indústria de São Paulo e também da Companhia Paulista de Estradas de Ferro. Ademais, J. Álvares Rubião Junior e J. Queiroz Lacerda eram diretores do banco e conselheiros da ferrovia, junto com Bento José de Carvalho, que era conselheiro nas duas firmas (Saes, 1986, p. 136).

28 As fontes de financiamento à indústria nacional, em que pese a carência de um banco de desenvolvimento antes de 1952, podiam vir do lançamento de debêntures e ações na Bolsa de Valores de São Paulo e do Rio de Janeiro, dos empréstimos concedidos pelos bancos, caso 
De outra parte, a Fábrica Votorantim passou a se valer do aumento nas receitas dos demais empreendimentos do Grupo - cal, cimento, ferrovia, venda de terrenos e renda de imóveis -, expediente que pôde dirimir os efeitos da crise têxtil, o que fazia da diversificação, surgida a partir da necessidade de atuar em um mercado em formação, uma importante fonte geradora de novas receitas ao grupo econômico (Colpan; Hikino, 2010, p. 41).

Por exemplo, conforme visto na tabela 3, no ano de 1927, a Fábrica Votorantim (unidade têxtil) gerou $68 \%$ das receitas do grupo - uma queda em relação ao seu patamar médio de $80 \%$-, enquanto a Seção de Terrenos respondeu por $13,3 \%$, a Estrada de Ferro Elétrica por 13,7\%, as Caieiras de Itupararanga por $4,2 \%$ e a Fábrica de Cimento Rodovalho por 0,8\%. Naquele momento, o Grupo tinha um grande empreendimento imobiliário na cidade de São Paulo, baseado na venda de seus terrenos no loteamento Brooklyn Paulista (atualmente Brooklyn Velho), iniciado em 1922. Conforme anúncio no jornal sorocabano O Cruzeiro do Sul, em 1925, a Votorantim vendia os terrenos a prestações sem juros e, ademais, por produzir materiais de construção - cal, cimento e tijolos em Itupararanga e Rodovalho podia fornecê-los a preços menores, o que, segundo a publicação, era motivo da grande procura pelos terrenos e, para os negócios do grupo, uma fonte de receitas que unia seus empreendimentos paralelos (SAFV, 1925).

Mesmo com dificuldades na atividade nuclear (têxtil), inferimos que houve certa expansão econômica da Votorantim na década de 1920 marcada pelo aumento do capital social do grupo, que passou de 5 mil contos de réis para 20 mil contos em 1927. Ademais, se o grupo sorocabano, assim como muitas firmas algodoeiras, amargava queda na produção, de outra parte, além dos empreendimentos que compunham o Grupo Votorantim, na própria lide têxtil houve certa diferenciação ao produzir tecidos de maior qualidade - a fábrica sorocabana produzia tecidos tintos, alvejados e estampados como zefir, morim, tecidos-fantasia (Loureiro, 2007, p. 50; Cano, 1981, p. 184; Suzigan, 1971, p. 93).

Em 1928, a Sociedade Anônima Fábrica Votorantim era a quarta maior firma do setor têxtil paulista, com um capital de 20 mil contos de réis, ficando atrás da Cia. Nacional de Tecidos de Juta (capital de 44 mil contos) - que prodos empréstimos hipotecários e, também, dos capitais próprios. Houve uma expansão dessas formas de crédito, que prescindiam da atuação estatal, entre 1890-1930, marcada, por exemplo, pelo aumento no número de empresas listadas nas Bolsas de Valores, sendo que 8,6\% do capital negociado na Bolsa de São Paulo em 1917 era proveniente de firmas têxteis (Hanley, 2005, p. 103; Marcondes, 2014, p. 759-782; Musacchio, 2009, p. 81). 
duzia tecidos à base de juta para sacos, baixeiros e passadeiras, principalmente sacos para acondicionar o café - e do Cotonifício Rodolpho Crespi (capital de 23 mil contos), que também atuava no ramo algodoeiro com a produção de brins, cassinetas, colchas e flanelas. ${ }^{29}$ Mas, com o espocar da Crise de 1929 que abalaria a economia nacional, bem como o setor têxtil, a resposta do grupo sorocabano aos efeitos da Crise aceleraria ainda mais a evolução da firma no setor têxtil paulista nos anos 1930, até chegar à liderança.

\section{A evolução da Sociedade Anônima Fábrica Votoran- tim e sua liderança no setor têxtil paulista (1929-1932)}

A Crise de 1929 agudizou ainda mais o cenário adverso vivido pelo ramo algodoeiro, sobretudo devido à queda nos preços do café e seus efeitos declinantes na demanda por artigos têxteis. Refletindo a retração geral da indústria paulista entre 1929-1930, o setor têxtil teve queda acentuada no número de operários, na produção e nos valores que ele gerou, crise marcada pela paralisação de importantes firmas algodoeiras. ${ }^{30}$

Conforme a tabela 4, houve um declínio no ativo da S. A. Fábrica Votorantim no ano de 1929, comparado à 1927, fato que se deu em virtude da depreciação nos valores do estoque de mercadorias e matérias-primas e, também, junto aos ativos permanentes do grupo (fábrica têxtil, terrenos, cimento, ferrovia, fábrica de cal). Queda ainda maior se deu com o patrimônio líquido em 1929 devido à utilização das reservas como forma de financiamento em meio à crise. A esse cenário de crise aglutinava-se o problema conjuntural de aumento das dívidas da Votorantim, pois naquele ano a conta diversos credores (passivo) representava o dobro da conta diversos devedores (ativo), fato que se evidencia pelo menor nível alcançado pelo quociente de cobertura total e pela liquidez corrente, denotando o ano de 1929 como o auge da crise para a Votorantim. ${ }^{31}$

\section{DEIC/SAIC/SP, 1928.}

30 Em 1929, o Estado de São Paulo tinha 22 empresas têxteis com atividades paralisadas em decorrência da crise, sendo 15 do ramo algodoeiro. Tomando o ano de 1928 como base, o número de operários no setor têxtil em 1930 era $28 \%$ menor, a produção de tecidos e seu valor caíram $30 \%$ no mesmo período. No ramo algodoeiro, o operariado declinou $44,2 \%$, queda que se deu de maneira análoga no valor da produção $(22,1 \%)$ e no capital investido $(10 \%)$ (Loureiro, 2006, p. 65; Suzigan, 1971, p. 96).

31 SÃO PAULO, 16/02/1928, p. 1953; 23/02/1930, p. 1995. No balanço patrimonial da S. A. Fábrica Votorantim para o ano de 1929, a conta devedores diversos somava 12.759 contos de 
Tabela 4 Contas do balanço patrimonial da Sociedade Anônima Fábrica Votorantim, 1927-1932 - valores reais em contos de réis (ano base $=1927$ )

\begin{tabular}{lr|r|r|r|r}
\hline & $\mathbf{1 9 2 7}$ & $\mathbf{1 9 2 9}$ & $\mathbf{1 9 3 0}$ & $\mathbf{1 9 3 1}$ & $\mathbf{1 9 3 2}$ \\
\hline Ativo & 89.622 & 72.923 & 81.914 & 94.851 & 93.927 \\
\hline Passivo & 49.803 & 49.340 & 55.073 & 62.097 & 60.258 \\
\hline Patrimônio líquido & 39.819 & 23.582 & 26.841 & 32.753 & 33.669 \\
\hline Quociente cobertura total & 1,811 & 1,478 & 1,497 & 1,542 & 1,558 \\
\hline Liquidez corrente & 0,652 & 0,646 & 0,651 & 0,687 & 0,659 \\
\hline \% Capital de terceiros no ativo total & 55,2 & 67,7 & 66,8 & 64,8 & 64,1 \\
\hline \% Capital próprio no ativo total & 44,8 & 32,3 & 33,2 & 35,2 & 35,8 \\
\hline Imobilização do Capital & 1,427 & 1,739 & 1,702 & 1,576 & 1,609 \\
\hline
\end{tabular}

Fonte: SÃO PAULO. Diário Oficial do Estado de São Paulo, 16/02/1928, p. 1953; 23/02/1930, p. 1995; 22/03/1931, p. 2327; 25/02/1932, p. 15.25/02/1933; p. 15.

Todavia, os indicadores patrimoniais do Grupo Votorantim em 1930, em que pese o aumento de $10,4 \%$ do passivo, apresentaram importante melhoria - aumento do ativo em $12 \%$ e do patrimônio líquido em $14 \%$ em relação a 1929. Esses números foram ainda mais significativos em 1931, quando o ativo cresceu $16 \%$ e o patrimônio líquido aumentou $22 \%$ em relação ao ano anterior, e seguiriam positivos em 1932, apontando uma saída da crise, que se iniciara em 1930. Em 1932, a S. A. Fabrica Votorantim passou inclusive a distribuir dividendos - naquele ano o montante foi de 650 contos de réis -, fato que se repetiria pelos dois anos seguintes e rompia com uma política do grupo que há uma década apontava reiteradamente em seus relatórios de diretoria a necessidade de não distribuir dividendos. ${ }^{32}$

A recuperação econômica da Votorantim, que se deu de maneira precoce já em 1930 - segundo a tabela 2 a produção da fábrica sorocabana foi de 17 milhões de metros naquele ano, sendo que havia sido de 16 milhões em 1929 - coaduna-se à explicação de Suzigan (1971, p. 96), Stein (1979, p. 152) e Cano (1981, p. 291), que demonstram que a produção têxtil brasileira e paulista voltou a crescer no ano de 1931, apoiada em algumas medidas conjunturais: desvalorização real do câmbio em 1930-1931; elevação das tarifas de importação dos tecidos e fios de algodão em 1929; p. $32 ; 27 / 02 / 1935$. 
decreto 19.739, de março de 1931, que proibia a importação de novas máquinas têxteis e de outros setores - podendo apenas ser importado maquinário para a reposição -; além do controle sobre as divisas (Suzigan, 2000, p. 162-163; Stein, 1979, p. 145).33

Porém, se os índices gerais de produção têxtil algodoeira cresciam, não se deve olvidar que nem todas as grandes firmas atravessavam uma conjuntura favorável, como demonstra Haber em relação às grandes firmas têxteis que atuavam no estado do Rio de Janeiro (incluindo a capital), caso da Cia. América Fabril, uma das maiores têxteis brasileiras naquele momento com capital de 32 mil contos de réis - o capital do Grupo Votorantim era de 20 mil contos. ${ }^{34}$ Esta, assim como outras têxteis fluminenses, apresentou quedas expressivas nas receitas e reservas entre 1929 e 1933, interrompendo a distribuição de dividendos e sofrendo perdas de $33 \% \mathrm{em}$ seus lucros (Haber, 1992, p. 344).

Em São Paulo, da mesma forma, diversas firmas têxteis tiveram suas atividades afetadas em decorrência da crise de 1929 e de fatores conjunturais, como a Revolução Constitucionalista. Um exemplo é a Tecelagem Ítalo-Brasileira, uma das maiores firmas têxteis que produzia tecidos e fitas de seda, que estava extremamente endividada em 1930; do Cotonifício Scarpa, que produzia tecidos de algodão e faliu naquele ano; e da São Paulo Alpargatas, que produzia tecidos crus, tintos e alvejados de algodão, chegou a entrar com pedido de falência, mas conseguiu renegociar suas dívidas e se manter em funcionamento. Devemos acrescentar que, em 1935, entraria em falência aquela que foi a maior firma têxtil paulista por cinco vezes entre 1928-1934, a Companhia Nacional de Tecidos de Juta, em decorrência da diminuição na demanda por sacaria para o café e outros produtos (Loureiro, 2006, p. 66 e 113; Suzigan, 2000, p. 170). ${ }^{35}$

33 Estas medidas ajudariam na recuperação do setor têxtil paulista a partir de 1933, ano em que todos os indicadores do setor apresentaram crescimento - número de operários, capital, valor da produção e força motriz -, mantendo-se esta conjuntura favorável ao setor até o final dos anos 1930, sendo que o índice de crescimento das firmas têxteis foi 6,5\% entre 1933-1939, contrabalançando a retração de -4,1\% entre 1928-1932 (Suzigan, 1971, p. 99; Loureiro, 2006, p. 101). 34 Haber (1992) analisa dados de lucratividade e distribuição de dividendos das seguintes companhias têxteis: Cia. Fiação e Tecidos Cometa, Cia. Fábrica de Tecidos São Pedro de Alcântara, Cia. Metropolitana, Cia. Progresso Industrial, Cia. de Fiação e Tecidos Aliança, Cia. de Fiação e Tecidos Confiança Industrial, Cia. América Fabril (esta com um capital de 32 mil contos de réis em 1927), Cia. de Fiação e Tecelagem Industrial Mineira (a única firma situada em Minas Gerais). 35 No Relatório da Diretoria da SAFV para o ano de 1930, há o relato dos efeitos adversos deflagrados a partir Crise de 1929: "O ano de 1930 não correu bem para a indústria, em geral, tendo sido mau para a indústria têxtil, em particular. As diversas flutuações cambiais, ocor- 
As falências de importantes concorrentes, aliadas às medidas adotadas pelo Grupo Votorantim no início da década de 1930 - e que serão descritas adiante - permitiram à Fábrica Votorantim alcançar a liderança do principal setor industrial paulista e brasileiro no ano de 1931, conforme a tabela 5 , fato que se repetiria na sequência do decênio.

Tabela 5 As maiores firmas têxteis do estado de São Paulo, 1929-1932 - segundo o capital investido (em contos de réis)

\begin{tabular}{|c|c|c|c|c|c|c|}
\hline Empresa & Local & $\begin{array}{l}\text { Capital } \\
\text { (contos } \\
\text { de réis) }\end{array}$ & $\begin{array}{l}\text { Ope- } \\
\text { rários }\end{array}$ & Teares & Fusos & Setor \\
\hline \multicolumn{7}{|l|}{1929} \\
\hline Cia. Nacional de Tecidos de Juta & Capital & 48.578 & 3.311 & 1.576 & 20.772 & juta \\
\hline S. A. Fábrica Votorantim & Sorocaba & 34.921 & 2.455 & 1.390 & 70.020 & algodão \\
\hline Tecelagem de Seda Ítalo-Brasileira & Capital & 28.950 & 1.053 & 560 & 0 & seda \\
\hline Cia. Nacional de Tecidos de Juta & Capital & 26.000 & 703 & 525 & 10.000 & algodão \\
\hline Cia. Nacional de Estamparia & Sorocaba & 25.215 & 1.200 & 1.100 & 42.000 & algodão \\
\hline \multicolumn{7}{|l|}{1930} \\
\hline Cotonifício Scarpa S. A. & Capital & 60.000 & 0 & 1.041 & 36.816 & algodão \\
\hline Cia. Nacional de Tecidos de Juta & Capital & 40.000 & 3.311 & 1.576 & 20.772 & juta \\
\hline S. A. Fábrica Votorantim & Sorocaba & 34.237 & 2.269 & 1.466 & 70.020 & algodão \\
\hline São Paulo Alpargatas Company & Capital & 23.763 & 367 & 300 & 10.000 & algodão \\
\hline Cia. Nacional de Estamparia & Sorocaba & 22.804 & 1.121 & 1.100 & 42.000 & algodão \\
\hline \multicolumn{7}{|l|}{1931} \\
\hline S. A. Fábrica Votorantim & Sorocaba & 38.672 & 2.817 & 1.498 & 69.628 & algodão \\
\hline Cia. Nacional de Tecidos de Juta & Capital & 37.000 & 3.311 & 0 & 20.772 & juta \\
\hline Cia. Nacional de Estamparia & Sorocaba & 24.411 & 1.435 & 1.146 & 40.960 & algodão \\
\hline São Paulo Alpargatas Company & Capital & 23.413 & 597 & 606 & 20.828 & algodão \\
\hline Tecelagem de Seda Ítalo-Brasileira & Capital & 22.572 & 1.500 & 582 & 0 & seda \\
\hline \multicolumn{7}{|l|}{1932} \\
\hline Cia. Nacional de Tecidos de Juta & Capital & 37.000 & 1.521 & 1.576 & 20.772 & juta \\
\hline Cia. Nacional de Estamparia & Sorocaba & 27.084 & 1.194 & 1.145 & 40.960 & algodão \\
\hline São Paulo Alpargatas Company & Capital & 24.700 & 662 & 600 & 16.300 & algodão \\
\hline
\end{tabular}

ridas durante o ano e principalmente a crise que assoberba o país inteiro, trouxeram muita instabilidade nos negócios. As inúmeras falências verificadas no decorrer de 1930 também influíram consideravelmente na marcha dos negócios, causando prejuízos às casas atacadistas de tecidos e às fábricas" (São Paulo, 22/03/1931, p. 2327). 
Tabela 5 (continuação)

\begin{tabular}{lrr|r|r|r|r|r}
\hline Empresa & Local & $\begin{array}{r}\text { Capital } \\
\text { (contos } \\
\text { de réis) }\end{array}$ & $\begin{array}{r}\text { Ope- } \\
\text { rários }\end{array}$ & Teares & Fusos & Setor \\
\hline S. A. Fábrica Votorantim & Sorocaba & 23.615 & 2.995 & 1.518 & 68.028 & algodão \\
\hline Tecelagem de Seda Ítalo-Brasileira & Capital & 22.572 & 1.144 & 592 & 0 & seda \\
\hline
\end{tabular}

Fonte: DEIC/SAIC/SP. Estatística Industrial do Estado de São Paulo, 1929-1932.

Obs: classificamos as empresas de acordo com o capital investido seguindo o modelo apresentado na documentação analisada, os dados da Estatística Industrial do Estado de São Paulo, que inclui no capital da empresa suas debêntures e os fundos de reserva.

\section{Os fatores de crescimento da Sociedade Anônima Fábrica Votorantim nos anos 1930}

De modo geral, a expansão da Fábrica Votorantim nos anos 1930 valeu-se de fatores conjunturais que também se fizeram presentes às congêneres têxteis: um mercado interno protegido e o uso mais intensivo da capacidade instalada. Porém, existiram especificidades no processo de crescimento do Grupo sorocabano que são desnudadas a partir da análise das ações que o Grupo empreendeu entre 1929-1932.

Primeiro, notamos que entre 1921 e 1931 o Conselho Fiscal do Grupo Votorantim aprovou, de forma contínua, a não distribuição de dividendos (retenção de lucros) aos acionistas, medida indicada pela diretoria do grupo, que era controlada por Antonio Pereira Ignácio (diretor-presidente) e, a partir de julho de 1926, contava com seu genro José Ermírio de Moraes (diretor-gerente), que se tornou o responsável pelas questões produtivas. ${ }^{36}$ Essa forma de financiamento, que se valia do capital próprio do grupo, foi utilizada tendo como justificativa a necessidade de repor o maquinário que se tornava obsoleto ao final da década de 1920. Principalmente, tal estratégia administrativa em meio à crise pode ser considerada como um fator-chave para o crescimento do grupo nos anos 1930, quando o acréscimo de maquinário - conforme a Tabela 4, o número de teares em 1929 que era de 1.300 passou a 1.518 e o de fusos saltou de 47.340 para 68.020 no ano

36 O pernambucano José Ermírio de Moraes, formado em engenharia de minas pela Colorado School of Mines (EUA), casou-se com Helena Pereira Ignácio no dia 18 de maio de 1925 na cidade de São Paulo (Caldeira, 2007, p. 52). 
de 1932 - representou uma elevação de capital investido e a possibilidade renovar as peças mais obsoletas. ${ }^{37}$

De maior importância, contudo, era a constituição da Votorantim enquanto um grupo econômico, ou seja, vários empreendimentos - presentes no ativo da SAFV - que compunham uma só estrutura empresarial, configurando-se essa condição de grupo econômico outro fator-chave para o crescimento da Votorantim no Entreguerras, pois, cada um desses empreendimentos gerava novas oportunidades de ganho e/ou ampliava os lucros das demais empresas do grupo.

Nesta perspectiva de um grupo econômico, os relatórios da diretoria da Votorantim destacam os vínculos entre os negócios do grupo. No setor têxtil, a Votorantim aprofundou sua integração produtiva, pois, no ano de 1931, em meio à crise que se abateu sobre a lavoura, o Grupo decidiu financiar plantadores de algodão da região de Sorocaba e zonas próximas a fim de garantir o fornecimento de matéria-prima que, por sua vez, era beneficiada em instalações próprias nas cidades de Cerqueira César, Itapetininga, Avaré e Conchas, possibilitando à Fábrica Votorantim superar seu recorde de produção. ${ }^{38}$

Ademais, em 1931 a produção têxtil da fábrica sorocabana valia-se dos trilhos da Estrada de Ferro Elétrica Votorantim, que desde julho de 1928 fazia parte da rede ferroviária estadual, sendo que "Não é pequena a vantagem da circulação facilitada assim dos produtos da Sociedade Anônima Fábrica Votorantim" (São Paulo. Diário Oficial do Estado de São Paulo, 25/02/1932, p. 15). Acerca da Fábrica Rodovalho, corria a extração de paralelepípedos, que atendeu à demanda de três localidades em 1931, além de fornecer paralelepípedos ao Grupo. Continuava a exploração de cal virgem e extinta nas Caieiras de Itupararanga ${ }^{39}$ - que também atendia à Fábrica Votorantim -,

37 São Paulo, 15/08/1922, p. 1222; 15/02/1923, p. 1184; 14/02/1925, p. 1233; 12/02/1926, p. $1243 ; 15 / 02 / 1928$, p. 1471; 23/02/1930, p. 1995; 22/03/1931, p. 2327; 25/02/1932, p. 15. No Relatório da Diretoria referente ao ano de 1929 consta "Atento aos constantes melhoramentos que vimos introduzindo nos diversos ramos, que constituem, em conjunto os fins e objetivos da Sociedade, não é aconselhável a distribuição de dividendos. A remodelação e aperfeiçoamento do maquinário exigiu o dispêndio de quantia avultada, que de futuro estamos certos, compensarão vantajosamente o sacrifício do presente" (São Paulo, 23/02/1930, p. 1995). 38 São Paulo, 25/02/1932, p. 15. No Relatório da Diretoria para o ano de 1931 constava que "A fábrica de tecidos de algodão e seda de Votorantim operou no máximo de sua capacidade". 39 A empresa Caieiras de Itupararanga, localizada em Sorocaba e pertencente ao Grupo Votorantim, era a segunda firma no setor de cal e cimento no Estado de São Paulo, conforme o capital investido, com um capital de 1.071 contos de réis, empregando 78 operários, uma força-motriz de 2 cavalos-elétricos e possuindo 1 forno para produção de cal. Nessa época, o 
bem como a venda de terrenos em São Caetano e no Brooklyn Paulista.

Tabela 6 Contas do balanço patrimonial da Sociedade Anônima Fábrica Votorantim, 1933-1939 - valores reais em contos de réis (ano base $=1933$ )

\begin{tabular}{l|r|r|r|r|r|r}
\hline & $\mathbf{1 9 3 3}$ & $\mathbf{1 9 3 4}$ & $\mathbf{1 9 3 5}$ & $\mathbf{1 9 3 6}$ & $\mathbf{1 9 3 8}$ & $\mathbf{1 9 3 9}$ \\
\hline Ativo & 94.851 & 93.928 & 96.040 & 99.188 & 107.992 & 100.169 \\
\hline Passivo & 59.912 & 63.583 & 71.092 & 59.048 & 61.399 & 63.832 \\
\hline Patrimônio líquido & 36.128 & 35.605 & 36.900 & 41.121 & 48.889 & 54.061 \\
\hline Liquidez corrente & 0,661 & 0,558 & 0,434 & 0,441 & 0,793 & 0,802 \\
\hline \% Capital de terceiros no ativo total & 60,7 & 66 & 63 & 59,6 & 54,8 & 54,1 \\
\hline \% Capital próprio no ativo total & 37,2 & 35,9 & 34 & 41,7 & 44,2 & 45,9 \\
\hline Imobilização do Capital & 1,607 & 1,533 & 2,137 & 1,767 & 1,276 & 1,234 \\
\hline
\end{tabular}

Fonte: São Paulo. Diário Oficial do Estado de São Paulo, 25/02/1934; p. 32; 27/02/1935, p. 40; 28/02/1936, p. 41;26/02/1937, p. 56; 20/02/1939, p. 48; 27/02/1940, p. 47.

Analisando os indicadores patrimoniais do Grupo Votorantim (tabela 6) entre 1933-1939, vemos que houve expansão no período, marcada pelo avanço semelhante do ativo (que era 5,4\% maior em 1939 do que 1933) e do passivo (que era 6,5\% maior em 1939 do que em 1933) e, principalmente, do patrimônio líquido (que era 50\% maior em 1939 do que em 1933). Percebemos que o Grupo Votorantim teve uma boa condição de solvência por todo o período, notada pelo quociente de cobertura total (ativo permanente mais ativo circulante, dividido pelo passivo circulante) - maior que 1 em toda a série - a mostrar que para cada unidade monetária de dívidas havia mais do que 1 unidade de ativos reais para quitá-las, demonstrando robustez do empreendimento.

A Votorantim mantinha valores elevados no indicador de imobilização do capital (ativo permanente dividido pelo patrimônio líquido), uma vez que, o valor equivalente a $160 \%$ do patrimônio líquido estava investido no ativo permanente entre 1933-1939, ou seja, boa parte do capital próprio da empresa encontrava-se imobilizado. Esta peculiaridade é corroborada pelo indicador de liquidez corrente (ativo circulante dividido pelo passivo circulante), pois, para cada unidade de dívida de curto prazo, a Votorantim 
tinha em média 0,7 unidades monetárias de ativos de curto prazo (disponibilidades) para quitar o débito. No que tange à solvência do grupo, notamos que isto não se traduziu em problemas de maior vulto, pois mesmo que a baixa liquidez corrente pudesse indicar um problema no curto prazo, todavia, o elevado montante de capital imobilizado poderia servir como garantia à obtenção de empréstimos bancários e demais captações junto a terceiros, o que garantiu a evolução dos negócios do Grupo em conjunto a uma estável condição de solvência indicada pelo quociente de cobertura total, como visto acima.

Analisando a Tabela 6, vemos que neste decênio o financiamento dava-se prioritariamente por meio do capital de terceiros (passivo circulante dividido pelo ativo total), sendo que, entre 1929-1932, eles haviam tido uma participação média de $66 \%$ em relação ao ativo total, percentual que caiu para a média 60\% entre 1933-1939. Essa redução atrelava-se à maior participação de capital próprio, o qual entre 1929-1933 representou 34\% das fontes de capitais e, para o restante dos anos 1930, chegaria a $40 \%$.

As receitas próprias tinham na segunda metade da década de 1930 fontes mais variadas, pois o Grupo ampliara seus empreendimentos. Em 1937, a Votorantim construíra outra usina de algodão na cidade paulista de Espírito Santo do Pinhal, o que dava à principal firma têxtil paulista a obtenção garantida de matéria-prima para suas atividades, ao articular-se com produtores e, posteriormente, montar estruturas para beneficiamento da fibra. ${ }^{40}$ Além do setor têxtil, o Grupo Votorantim iniciou em terras sorocabanas, no ano de 1933, a construção da Fábrica de Cimento Santa Helena, que foi inaugurada em 1934 para produzir o Cimento Votoran com um forno importado da Dinamarca e acabou se tornando a segunda maior firma paulista do setor. Os sacos de cimento eram levados de Sorocaba para os mercados consumidores, sobretudo para a cidade de São Paulo, pelos trilhos da Estrada de Ferro Votorantim, tornando-se nova e importante fonte de receitas ao Grupo. ${ }^{41}$

Dessa forma, na Estatística Industrial do Estado de São Paulo de 1937, o Grupo Votorantim aparecia em variados setores:

40 O Relatório da Diretoria da SAFV para o ano de 1931 (São Paulo, 25/02/1932, p. 15) dizia que a "A Sociedade Anônima Fábrica Votorantim procura de modo positivo dentro de sua atividade peculiar, ajustar em um só complexo econômico a produção agrícola e a industrial". 41 Em 1938, a Votorantim teve um impulso na demanda por cimentos ao vencer a licitação para remodelação do Viaduto do Chá, na cidade de São Paulo, obra em que foi utilizado o Cimento Votoran (Caldeira, 2007, p. 81). 
- Fábrica Votorantim (Sorocaba-SP): fiação e tecelagem de algodão com a Fábrica Votorantim (capital de 61 mil contos e 3.500 operários para a produção de fios estampados, crus e tintos) e outra unidade na cidade de Espírito Santo do Pinhal (capital de 500 contos de réis e 214 operários que cuidavam da fiação); óleos vegetais e sub-produtos na Fábrica Votorantim (capital de 670 contos de réis e 321 operários para a produção de óleo de semente de algodão, linter, torta e estearina); sabão e saponáceo na Fábrica Votorantim (capital de 120 contos e 18 operários para a produção de sabão comum; olarias com a Fábrica Votorantim (capital 10 contos de réis e 18 operários para a fabricação de tijolos).

- Fábrica de Cimento Santa Helena (Sorocaba-SP): cimento e cal com a Fábrica Santa Helena (capital de 15 mil contos e 664 operários para a fabricação de cimento); adubos e colas nas Caieiras de Santa Helena (capital de 5 contos de réis e 4 operários para a produção de adubos de origem mineral).

- Fábrica Rodovalho (São Roque-SP): cimento e cal com a Fábrica Rodovalho (capital de 180 contos e 23 operários para extração de cal).

- Oficinas de estradas de ferro com a oficina da E. F. Votorantim (situada em Sorocaba, com capital de 30 contos de réis e 63 operários para reparos de bondes e vagões).

- Usina do Itupararanga (Sorocaba-SP): energia elétrica com a usina na Represa do Itupararanga (com capital total de 420 contos e 42 operários) para fornecimento de energia às fábricas do grupo, bem como venda de energia às localidades próximas (DEIC/SAIC/SP. Estatística Industrial do Estado de São Paulo, 1937, p. 45, 126, 157, 174, 196, 198, 199 e 246).

No decorrer dos anos 1930, o Grupo Votorantim calcado em sua capacidade produtiva, nos capitais de terceiros e na acumulação gerada pelos diversos empreendimentos, além da recuperação da economia brasileira e de seus efeitos positivos para a demanda têxtil, expandiu-se e pôde, inclusive, quitar seu empréstimo em Londres em 1938 - cujo vencimento era apenas para o ano de 1946. Neste final de decênio, o Grupo contava com maior participação de capital próprio como proporção do ativo total, a demonstrar a lucratividade de um conglomerado que, entre seus ativos, possuía a Fábrica Votorantim, a principal empresa têxtil do Estado de São Paulo. 
Tabela 7 As maiores firmas têxteis do Estado de São Paulo, 1934-1937 - segundo o capital investido

\begin{tabular}{|c|c|c|c|c|c|c|}
\hline Empresa & Local & $\begin{array}{r}\text { Capital } \\
\text { (contos) }\end{array}$ & $\begin{array}{l}\text { Ope- } \\
\text { rários }\end{array}$ & Teares & Fusos & Setor \\
\hline \multicolumn{7}{|l|}{1934} \\
\hline Cia. Nacional de Tecidos de Juta & Capital & 110.197 & 1.521 & 1.576 & 20.772 & juta \\
\hline S. A. Fábrica Votorantim & Sorocaba & 67.091 & 3.785 & 1.580 & 67.640 & algodão \\
\hline Cia. Nacional de Estamparia & Sorocaba & 43.721 & 1.770 & 1.145 & 40.960 & algodão \\
\hline $\begin{array}{l}\text { Fiação, Tecelagem e Estamparia } \\
\text { Ypiranga "Jafet" S. A. }\end{array}$ & Capital & 36.741 & 1.952 & 1.449 & 45.000 & algodão \\
\hline $\begin{array}{l}\text { S. A. Tecelagem de Seda Ítalo- } \\
\text {-Brasileira }\end{array}$ & Capital & 35.994 & 1.201 & 637 & 0 & seda \\
\hline \multicolumn{7}{|l|}{1935} \\
\hline S. A. Fábrica Votorantim & Sorocaba & 68.928 & 3.830 & 1.580 & 67.640 & algodão \\
\hline Cotonifício Rodolpho Crespi S. A. & Capital & 58.232 & 2.799 & 728 & 4.000 & algodão \\
\hline $\begin{array}{l}\text { S. A. Tecelagem de Seda Ítalo- } \\
\text {-Brasileira }\end{array}$ & Capital & 47.631 & 1.261 & 626 & 0 & seda \\
\hline $\begin{array}{l}\text { Indústrias Reunidas Francisco } \\
\text { Matarazzo }\end{array}$ & Capital & 37.936 & 2.296 & 1.972 & 55.216 & algodão \\
\hline $\begin{array}{l}\text { Fiação, Tecelagem e Estamparia } \\
\text { Ypiranga "Jafet" S. A. }\end{array}$ & Capital & 37.520 & 2.391 & 1.600 & 45.000 & algodão \\
\hline \multicolumn{7}{|l|}{1936} \\
\hline S. A. Fábrica Votorantim & Sorocaba & 68.928 & 3.400 & 1.580 & 67.412 & algodão \\
\hline $\begin{array}{l}\text { Cia. Brasileira de Linhas para } \\
\text { Coser S/A }\end{array}$ & Capital & 45.901 & 1.270 & 0 & 0 & $\begin{array}{r}\text { linhas } \\
\text { para coser } \\
\text { e bordar }\end{array}$ \\
\hline $\begin{array}{l}\text { S. A. Tecelagem de Seda Ítalo- } \\
\text {-Brasileira }\end{array}$ & Capital & 40.538 & 1.631 & 561 & 0 & seda \\
\hline $\begin{array}{l}\text { Indústrias Reunidas Francisco } \\
\text { Matarazzo (Belenzinho) }\end{array}$ & Capital & 37.261 & 2.432 & 1.973 & 55.216 & algodão \\
\hline $\begin{array}{l}\text { Indústrias Reunidas Francisco } \\
\text { Matarazzo }\end{array}$ & $\begin{array}{r}\text { São } \\
\text { Bernardo }\end{array}$ & 36.614 & 1.343 & 0 & 0 & seda \\
\hline \multicolumn{7}{|l|}{1937} \\
\hline S. A. Fábrica Votorantim & Sorocaba & 61.641 & 3.500 & 1.580 & 67.068 & algodão \\
\hline Cia. Nitro-Química Brasileira & $\begin{array}{r}\text { São } \\
\text { Miguel }\end{array}$ & 59.000 & 1.700 & 0 & 0 & seda \\
\hline
\end{tabular}


Tabela 7 (continuação)

\begin{tabular}{|c|c|c|c|c|c|c|}
\hline Empresa & Local & $\begin{array}{r}\text { Capital } \\
\text { (contos) }\end{array}$ & $\begin{array}{l}\text { Ope- } \\
\text { rários }\end{array}$ & Teares & Fusos & Setor \\
\hline $\begin{array}{l}\text { Cia. Brasileira de Linhas para } \\
\text { Coser S/A }\end{array}$ & Capital & 54.224 & 1.397 & 0 & 0 & $\begin{array}{r}\text { linhas } \\
\text { para cose } \\
\text { e bordar }\end{array}$ \\
\hline $\begin{array}{l}\text { S. A. Tecelagem de Seda Ítalo- } \\
\text {-Brasileira }\end{array}$ & Capital & 39.109 & 1.710 & 696 & 0 & seda \\
\hline $\begin{array}{l}\text { Fiação, Tecelagem e Estamparia } \\
\text { Ypiranga "Jafet" S. A. }\end{array}$ & Capital & 35.000 & 2.745 & 1.600 & 47.884 & algodão \\
\hline
\end{tabular}

Fonte: DEIC/SAIC/SP. Estatística Industrial do Estado de São Paulo, 1934-1937.

Obs: no capital da empresa estão inclusas suas debêntures e os fundos de reserva.

O avanço no mercado paulista fazia da Fábrica Votorantim uma das maiores empresas têxteis não só do Estado, bem como do Brasil, com seu capital de 68.928 contos de réis em 1935 e 1936. Ela ficava atrás somente da Cia. América Fabril, firma fluminense cujo capital somado às reservas totalizava 90.084 contos de réis, sendo a única empresa a rivalizar com as têxteis paulistas no volume de capitais. ${ }^{42}$

Pela tabela 7, constatamos que a Fábrica Votorantim - que produzia tecidos estampados, crus, alvejados e tintos, lenços - tornou-se a maior firma têxtil paulista entre os anos 1935-1937, segundo o capital investido, superando tradicionais concorrentes do ramo algodoeiro, como as Indústrias Reunidas Francisco Matarazzo - que produziam tecidos tintos, estampados e brancos - bem como de outros ramos, caso da Tecelagem de Seda Ítalo-Brasileira (produzia tecidos e fitas de seda). Todavia, essa ascensão da têxtil sorocabana não destoa do que se viu na maioria de suas congêneres no que tange à capacidade produtiva, pois a Votorantim não teve grande ampliação no seu número de teares: eram 1.498 máquinas no ano de 1932, e que totalizavam 1.580 em 1937.

Neste sentido, a trajetória do Grupo Votorantim durante a década de 1930 enquadra-se no exposto por Stein e Cano, quando eles expõem que as medidas governamentais limitando a importação de maquinário apenas às peças de reposição teriam proporcionado às grandes empresas têxteis, que na década de 1920 haviam previamente modernizado suas instala- 
ções - caso da Votorantim -, a possibilidade de ampliar a produção para um mercado que se encontrava protegido da concorrência internacional, em virtude da desvalorização cambial e das taxas sobre as importações e, também, dos concorrentes nacionais que encontravam dificuldades para formar novas fábricas dados os limites da importação (Stein, 1979, p. 152; Cano, 1981, p. 99). ${ }^{43}$

\section{Considerações finais}

Este artigo buscou evidenciar os elementos fundamentais que levaram o Grupo Votorantim a tornar-se detentor da maior firma têxtil paulista na década de 1930. O ponto de partida dessa trajetória foi a compra por Antonio Pereira Ignácio da Fábrica Votorantim e das demais empresas componentes do grupo (Caieiras de Itupararanga e Estrada de Ferro Elétrica Votorantim), os quais ele agregou à Fábrica de Cimento Rodovalho, compondo o Grupo Votorantim.

Com o controle acionário de Pereira Ignácio e da visão administrativa de José Ermírio de Moraes, o Grupo Votorantim adotou a política de não-distribuição de dividendos por toda a década de 1920 e início dos anos 1930. Tal medida administrativa ampliou as reservas do grupo que, em meio à crise econômica entre 1929-1932, viu-se munido de capital próprio para aproveitar uma conjuntura em que seus principais concorrentes soçobravam. Nesse período, o grupo adquiriu novos teares e fusos, expandindo a capacidade produtiva da fábrica sorocabana, o que permitiu alcançar um recorde na produção de tecidos de algodão em 1931, primeiro ano em que a Votorantim tornou-se líder no setor têxtil paulista, segundo o capital investido.

Essa liderança, novamente atingida entre 1935-1937, teve também como fatores-chave os capitais de terceiros e a organização como grupo econômico. Sobre os capitais de terceiros, eles se constituíram como a maior fonte de capitalização durante todo o período analisado, destacando-se o empréstimo obtido em Londres no ano de 1926 e que veio a reforçar as finanças do grupo antes de 1929, quando escasseariam as fontes institucionais de crédito.

43 Stein (1979, p. 148-152) aponta que as restrições à importação de máquinas têxteis estimularam o surgimento de algumas firmas nacionais produtoras de teares que, junto da revenda de teares usados, respondiam pela ampliação de capacidade instalada de algumas firmas têxteis. 
Em relação à constituição como grupo econômico, a Votorantim conseguia vincular seus diversos empreendimentos no intuito de permitir que cada um deles gerasse renda e reforçasse a acumulação dos outros ativos. Da ferrovia que transportava os tecidos e os sacos de cimento aos mercados consumidores, passando pela usina própria que alimentava as instalações fabris na região de Sorocaba, nota-se a formação de um grupo com ativos integrados e produtos diversificados, concentrados no setor têxtil paulista, mas com presença nos ramos de cimento e cal, olarias, adubos, sabão, óleos vegetais, oficinas de trem e energia elétrica. Esses empreendimentos eram fundamentais à unidade têxtil, pois diminuíam seus custos, por exemplo, relativos ao transporte e aquisição de matéria-prima, permitindo à Fábrica Votorantim consolidar-se como a maior firma têxtil do Estado de São Paulo nos anos 1930.

Por fim, é relevante notar que se atualmente o Grupo Votorantim é o maior conglomerado industrial de origem privada no Brasil, o início dessa trajetória baseou-se na liderança alcançada pelo grupo no setor têxtil. A guinada da Votorantim para o setor industrial de base, no decorrer da década de 1930 e 1940, esteve alicerçada na acumulação gerada principalmente pela Fábrica Votorantim, a unidade têxtil do grupo. Os empreendimentos no setor siderúrgico (Siderúrgica Barra Mansa), setor químico (Cia. Nitroquímica), setor de cimento e cal (Cimento Votoran e Poty) e no setor de alumínio (Companhia Brasileira de Alumínio) valeram-se dos capitais gerados pelo principal investimento do grupo naqueles anos, a unidade têxtil sorocabana Fábrica Votorantim.

\section{Referências}

ALDRIGHI, D. M.; POSTALI, F. A. S. Business groups in Brazil. In: COLPAN, A. M.; HIKINO, T.; LINCOLN, J. R. The Oxford Handbook of business groups. Oxford: Oxford University Press, 2010.

AURELIANO, L. No limiar da industrialização. Campinas: UNICAMP/IE, 1999.

BAER, W. A economia brasileira. São Paulo: Nobel, 2002.

BAER, W. A industrialização e o desenvolvimento econômico do Brasil. Rio de Janeiro: Fundação Getúlio Vargas, 1975.

BARBERO, M. I. Los grupos económicos en la Argentina en una perspectiva de largo plazo (siglos XIX y XX).In: JONES, G.; LLUCH, A. El Impacto Histórico de la globalización en Argentina y Chile: empresas y empresarios. Buenos Aires: Temas, 2011. 
BONELLI, R. As estratégias dos grandes grupos industriais brasileiros nos anos 90. Brasília: Ipea, Texto para Discussão 569, jul. 1998.

CALDEIRA, J. Votorantim 90 anos: uma história de trabalho e superação. São Paulo: Mameluco, 2007.

CANO, W. Da Década de 1920 à de 1930: Transição Rumo à Crise e à Industrialização no Brasil. Revista EconomiA, Brasília(DF), v. 13, n. 3b, p.897-916, set./dez. 2012.

CANO, W. Raizes da concentração industrial em São Paulo. T. A. Queiroz, 1981.

CARONE, E. A evolução industrial de São Paulo (1889-1930). São Paulo: Editora Senac, 2001.

COLPAN, A. M.; HIKINO, T. Diversified Business Groups in the West: History and Theory. Harvard Business School Research Paper Series \# 17-035, octuber, 2016.

COLPAN, A. M.; HIKINO, T. Foundations of business groups: towards an integrated framework. In: COLPAN, A. M.; HIKINO, T.; LINCOLN, J. R. The Oxford Handbook of business groups. Oxford: Oxford University Press, 2010.

DEAN, W. A Industrialização de São Paulo. São Paulo: Difel, 1971.

DEIC/SACOP/SP. Boletim da Diretoria de Indústria e Comércio para o ano de 1922. São Paulo: agosto e setembro de 1918; fevereiro e março de 1922.

DEIC/SAIC/SP. Estatística Industrial do Estado de São Paulo, 1928-1937.

EFEV. Breve histórico da Estrada de Ferro Elétrica Votorantim (EFEV). São Paulo: S. A. Indústrias Votorantim, 1980

FERNÁNDEZ-PEREZ, P.; CASANOVA, L. Algunas claves de la longevidad de las grandes empresas familiares brasileñas. Apuntes, Universidad del Pacífico, v. 39, n. 70, p. 273-300, $1^{\circ}$ semestre 2012.

FERNÁNDEZ-PEREZ, P. The study of family businesses from a global perspective: possibilities and limitations. História Econômica \& História de Empresas. São Paulo, v. 13, n. 2, p. 147-167, 2010.

FISHLOW, A. Origens e consequências da substituição de importação no Brasil. Estudos Econômicos. v. 2, n. 6, dez. 1972, p. 7-76.

GONÇALVES, R. Capital financeiro, bancário e industrial no Brasil. Economia e Sociedade, Campinas, SP, (13), p. 179-189, dez. 1999.

GONÇALVES, R. Grupos econômicos: uma análise conceitual e teórica. Revista Brasileira de Economia, Rio de Janeiro, v. 45, n. 4, p. 491-518, out./dez. 1991.

GRANOVETTER, M. Business groups and social organization. In: SMELSER, N. J.; SWEDBERG, R. The handbook of economic sociology. Oxfordshire: Princeton University Press, Princeton, 2005.

HABER, S. Business Enterprise and the Great Depression in Brazil: A Study of Profits and Losses in Textile Manufacturing. Business History Review, 66, Summer 1992, p. 335-363.

HANLEY, A. G. Native capital: financial institutions and economic development in Sao Paulo, Brazil, 1850-1920. Stanford, Calif.: Stanford University, 2005.

KHANNA, T.; YAFEH, Y. Business Groups in Emerging Markets: Paragons or Parasites? Journal of Economic Literature, Vol. XLV, p. 331-372, junho 2007. 
KIM, D.; KANDEMIR, D.; CAVUSGIL, S. T. The role of family conglomerates in emerging markets: what western companies should know. Thunderbird international business review, v. 46, p. 13-38, jan./feb. 2004.

LEFF, N. Industrial organization and entrepreneurship in the developing countries: the economic groups. Economic development and cultural change, 26, p. 661-675, março, 1978.

LIMA, J. D.; SANSON, J. R. O surto de industrialização do setor têxtil a partir de 1880: Blumenau e Brasil. Heera: Revista de História Econômica \& Economia Regional Aplicada - v. 3, n. 5 jul.-dez. 2008.

LLOYD, R. et al. Impressões do Brazil no século vinte. Londres: Lloyd's Greater Britain Plublishing Company, 1913.

LOUREIRO, F. P. Nos fios de uma trama esquecida: a indústria têxtil paulista nas décadas pós-Depressão (1929-1950). São Paulo. Dissertação (Mestrado) - Faculdade de Filosofia, Letras e Ciências Humanas, Universidade de São Paulo, 2007.

LUZ, N. V. A luta pela industrialização do Brasil: 1808 a 1930. São Paulo: Alfa-Omega, 1975.

MARCONDES, R. L. e HANLEY, A. G. Bancos na transição republicana em São Paulo: o financiamento hipotecário (1888-1901). Estud. Econ., São Paulo, v. 40, n. 1, Mar. 2010.

MARCONDES, R. L. Crédito privado antes da grande depressão do século XX: o mercado hipotecário. Estud. Econ. [online]. 2014, v. 44, n. 4 [cited 2015-04-30], p. 749-786.

MARCOVITCH, J. Pioneiros \& Empreendedores. v 2. São Paulo: EDUSP, 2009.

MARSON, M. D. Comércio e indústria: estrutura das empresas no estado de São Paulo, 1911-1920. Seminário sobre a economia mineira (17.: 2016 : Diamantina, MG), XVII Seminário sobre a economia mineira [recurso eletrônico]: anais. Belo Horizonte: UFMG/Cedeplar, 2016.

MUSACCHIO, A. Experiments in financial democracy: corporate governance and financial development in Brazil, 1882-1950. New York: Cambridge University Press, 2009.

NEGRI, B. Concentração e desconcentração industrial em São Paulo (1880-1990). Campinas: UNICAMP, 1996.

OBSERVADOR. O Observador Econômico e Financeiro. n. 6, julho de 1936.

PEDROSA, R. P. A. Desafios do crescimento de empresas diversificadas: os casos Matarazzo e Votorantim. Rio de Janeiro: Coppead/UFRJ, dissertação de mestrado, 2015.

RIBEIRO, M. A. R. Condições de trabalho na indústria têxtil paulista (1870-1930). São Paulo, SP: Hucitec: Editora da UNICAMP, 1988.

SAES, A. M. Conflitos do Capital. Bauru, SP: Edusc, 2010.

SAES, F. A. M. Crédito e bancos no desenvolvimento da economia paulista, 1850-1930. São Paulo: IPE/USP, 1986.

SAFV. Anúncio publicitário no jornal O Cruzeiro do Sul sobre a venda de terrenos no Brooklyn Paulista, ano de 1925. São Paulo: Centro de Memória Votorantim.

SAFV. Balanço da Sociedade Anônima Fábrica Votorantim para o ano de 1923. São Paulo: Centro de Memória do Grupo Votorantim.

SAFV. Livro Diário da Sociedade Anônima Fábrica Votorantim (SAFV) para o ano de 1918-1919. São Paulo: Centro de Memória do Grupo Votorantim. 
SANTOS, L. B. Reestruturação, internacionalização e novos territórios de acumulação do Grupo Votorantim. Presidente Prudente, SP: FCT/UNESP, dissertação de mestrado, 2008.

SÃO PAULO. Diário Oficial do Estado de São Paulo, 1921-1940. Consulta aos balanços contábeis, demonstrações de lucros e perdas, e aos relatórios de diretoria da Sociedade Anônima Fábrica Votorantim.

STEIN, S. J. Origens e evolução da indústria têxtil no Brasil, 1850-1950. Rio de Janeiro: Campus, 1979.

SUZIGAN, W. A Industrialização de São Paulo: 1930-1945. Revista Brasileira de Economia. Rio de Janeiro, v. 25, n. 2, p. 89-111, 1971.

SUZIGAN, W. Indústria Brasileira: origem e desenvolvimento. São Paulo: Hucitec/ Ed. Unicamp, 2000.

VERSIANI, F. R.; VERSIANI, M. T. A indústria brasileira antes de 1930: uma contribuição. In: VERSIANI, F. R.; MENDONÇA DE BARROS, J. R. Formação econômica do Brasil. São Paulo: Saraiva, 1978.

VILLELA, A. V.; SUZIGAN, W. Politica do governo e crescimento da economia brasileira, 1889-1945. Rio de Janeiro: IPRA/INPES, 1973.

\section{Sobre os autores}

Gustavo Pereira da Silva-gusttavopereira@yahoo.com.br

Departamento de Economia da Universidade Federal de São Carlos (UFSCar), Sorocaba, São Paulo.

Armando João Dalla Costa - ajdcosta@uol.com.br

Departamento de Economia da Universidade Federal do Paraná (UFPR), Curitiba, Paraná.

A pesquisa é resultado parcial do projeto S.A. Indústrias Votorantim (1925-1980): formação e expansão de um grupo econômico no desenvolvimento industrial do Brasil pertencente à Chamada MCTI/CNPq/MEC/CAPES n. 43/2013.

Ademais, agradecemos aos funcionários do Centro de Memória Votorantim (São Paulo-SP) pelo auxílio em nossa pesquisa.

\section{Sobre 0 artigo}

Recebido em 01 de junho de 2016. Aprovado em 06 de fevereiro de 2017. 